\section{Improving Undergraduate Life Science Education for the Biosciences Workforce: Overcoming the Disconnect between Educators and Industry}

\author{
Christopher Thompson, ${ }^{\dagger}$ Joseph Sanchez, ${ }^{\ddagger}$ Michael Smith,$\$$ Judy Costello, \\ Amrita Madabushi,, Natasha Schuh-Nuhfer," Rommel Miranda, ${ }^{\circledR}$ Brian Gaines, ** \\ Kathleen Kennedy, ${ }^{\mathrm{T}}$ Michael Tangrea, ${ }^{+{ }^{+}}$and David Rivers ${ }^{\text {t* }}$ \\ ${ }^{\dagger}$ Department of Biology, Loyola University Maryland, Baltimore, MD 21210; ${ }^{\star}$ AstraZeneca, Inc., \\ Frederick, MD 21703; 'Biotechnology Program, Montgomery College, Germantown, MD 20876; \\ "BioHealth Innovation, Inc., Rockville, MD 20850; "Life Sciences Institute, Baltimore City \\ Community College, Baltimore, MD 21215; ${ }^{\# T e a c h e r ~ E n r i c h m e n t ~ P r o g r a m, ~ C e n t e r ~ f o r ~ E x c e l l e n c e ~}$ \\ in Education, McLean, VA 22102; ${ }^{\circledR}$ Department of Physics, Astronomy, and Geosciences, Towson \\ University, Towson, MD 21252; **MDBio Foundation, Inc., Gaithersburg, MD 20878; "AAlvin and \\ Lois Lapidus Cancer Institute, Sinai Hospital, Baltimore, MD 21215
}

\begin{abstract}
The BioHealth Capital Region (Maryland, Virginia, and Washington, DC; BHCR) is flush with colleges and universities training students in science, technology, engineering, and mathematics disciplines and has one of the most highly educated workforces in the United States. However, current educational approaches and business recruitment tactics are not drawing sufficient talent to sustain the bioscience workforce pipeline. Surveys conducted by the Mid-Atlantic Biology Research and Career Network identified a disconnect between stakeholders who are key to educating, training, and hiring college and university graduates, resulting in several impediments to workforce development in the BHCR: 1) students are underinformed or unaware of bioscience opportunities before entering college and remain so at graduation; 2 ) students are not job ready at the time of graduation; 3 ) students are mentored to pursue education beyond what is needed and are therefore overqualified (by degree) for most of the available jobs in the region; 4) undergraduate programs generally lack any focus on workforce development; and 5) few industry-academic partnerships with undergraduate institutions exist in the region. The reality is that these issues are neither surprising nor restricted to the BHCR. Recommendations are presented to facilitate improvement in the preparation of graduates for today's bioscience industries throughout the United States.
\end{abstract}

\section{INTRODUCTION}

Career opportunities for life science graduates are on the rise, especially in career tracks commonly referred to as "nontraditional" or "alternative" pathways (Fuhrmann et al., 2011; Blank et al., 2017; Roach and Sauermann, 2017). These so-called nontraditional paths are associated with any bioscience career outside medicine, allied health, or academia. Whether this designation is even appropriate is open for debate, as several reports (Fuhrmann et al., 2011; Stephan, 2012) indicate that far fewer graduates trained in the life sciences are pursuing traditional careers and that graduates are instead seeking broader employment opportunities, such as in bioscience industries or non-research related positions. There are many purported reasons for this shift, but among the most significant are a decline in academic research positions and expansive growth in biohealth and bioscience industries throughout the United States (National Institutes of Health, 2012; TEConomy/Biotechnology Innovation Organization, 2016). This has, in turn, equated with new branches in the career
Adele Wolfson, Monitoring Editor Submitted Mar 30, 2018; Revised Jun 7, 2018; Accepted Jun 11, 2018

CBE Life Sci Educ September 1, 2018 17:es12 DOI:10.1187/cbe.18-03-0047

*Address correspondence to: David Rivers (drivers@loyola.edu).

(c) 2018 C. Thompson et al. CBE-Life Sciences Education ๑ 2018 The American Society for Cell Biology. This article is distributed by The American Society for Cell Biology under license from the author(s). It is available to the public under an Attribution-Noncommercial-Share Alike 3.0 Unported Creative Commons License (http://creativecommons.org/licenses/ by-nc-sa/3.0).

"ASCB®" and "The American Society for Cell Biology $\AA^{\prime \prime}$ are registered trademarks of The American Society for Cell Biology. 
pipeline not previously available and/or considered by life science graduates (Fuhrmann et al., 2011).

The BioHealth Capital Region (BHCR) comprising Maryland, Virginia, and Washington, DC, in many ways serves as a microcosm of the changing employment trends in the life sciences. The region represents one of the fastest-growing biohealth clusters in the United States. Unprecedented growth in the region's bioscience industries has occurred since 2001, with more than 1300 biohealth-related companies now located in the BHCR (Maryland Department of Commerce, 2018). The burgeoning industry has led to creation of more than 300,000 jobs in Greater Baltimore, Virginia, and metropolitan DC during the past decade. The potential exists for the workforce to double by 2023 (BioHealth Capital Region, 2018). Contributing to this growth potential is the BHCR's proximity to several government agencies (e.g., National Institutes of Health, National Cancer Institute, U.S. Department of Agriculture, Food and Drug Administration, National Institute of Standards and Technology, and others) that offer a steady supply of experienced scientists for collaboration and possible employment. It thus comes as a surprise that growth in the region has been limited by the inability to attract and retain a sufficient workforce, especially for entrylevel positions that require bachelor's degrees. Talent seekers consistently report that jobs remain vacant for extended periods of time, positions go unfilled, and competent employees are recruited away to larger markets. The biggest pool of potential talent resides within the region's colleges and universities. More than 100,000 undergraduate students are enrolled in science, technology, engineering, and mathematics (STEM) programs throughout the BHCR that, in turn, should serve as a direct talent pipeline for the bioscience workforce (Economic Alliance of Greater Baltimore, 2013). Likewise, the BHCR represents one of the most highly educated markets in the United States and educate tens of thousands of students in biohealth-related fields annually (Maryland BioTechnology Center, 2010). However, this impressive output of students trained in STEM disciplines has not translated into bioscience workforce talent.

Why? Some contend that 4-year institutions in the United States rebuff the notion that job training should be part of their mission (Porter, 2008), leaving so-called vocational education to 2 -year programs. The contrasting view is that life science companies believe that the necessary basic training and education be done before beginning the job (Dahms, 2003; Porter, 2008). In other words, it is not industry's responsibility to do the job of academia (Porter, 2008). Thus, a philosophical and pedagogical impasse exists between what employers expect and educators believe or do. These attitudes may well contribute to the workforce shortage in the BHCR, but no one in the region has successfully uncovered the answer to the problem. As a consequence, the Mid-Atlantic Biology Research and Career (MABRC) network was formed with the intention of trying to uncover the factors contributing to the workforce shortage and developing potential solutions. The network formed in 2016 with the primary objectives of determining the essential technical and professional skills needed in the region's biosciences workplaces and evaluating whether traditional undergraduate life science curricula equip graduates with these skills. These objectives were based on two premises regarding the workforce shortage in the BHCR: 1) most undergraduates are not aware, or are aware only at an ancillary level, of career opportunities in bioscience industries, government, and the private sector; and 2) regardless of student knowledge of alternative careers, the majority lack the necessary technical and/or professional ("soft") skills required for these workplaces (Araneo et al., 2017; Strauss, 2017; Tate, 2017). For acquisition of data on skills sought by employers and those inherent to undergraduate life science curricula, a series of surveys were developed (see the Supplemental Material BioHealth Capital Region Employer Partnership Survey) and then administered electronically (i.e., through email solicitations or via tablets at career conferences and networking events) to stakeholders who were key to educating, training, and hiring college graduates. Stakeholders surveyed included employers (e.g., hiring managers, talent acquisition recruiters, and industry scientists), program directors/chairs of undergraduate life sciences programs, university career counselors, and undergraduate students (including those currently matriculating and recent graduates) located in the BHCR (Table 1).

What was uncovered is that a severe disconnect exists between all stakeholders. Students, faculty, and career counselors are underinformed about a wide range of career opportunities that lie outside the traditional career mentoring received at colleges and universities. Concomitantly, bioscience industries in the BHCR have done a relatively poor job of marketing entrylevel careers to academia. The end result is that several obstacles exist that impede the preparation, recruitment, and hiring of graduates from undergraduate programs. This essay offers insight into the skills (e.g., technical, professional, and business acumen) that industry representatives indicated are desired in

TABLE 1. Survey demographics and response rate of stakeholders in $B H C R^{a}$

\begin{tabular}{|c|c|c|c|c|}
\hline \multirow[b]{2}{*}{ Stakeholders } & \multirow[b]{2}{*}{ Area of representation } & \multicolumn{2}{|c|}{ Number } & \multirow[b]{2}{*}{$\%$ response } \\
\hline & & Contacted & Responded & \\
\hline Industry & $\begin{array}{c}\text { Biologics, biomanufacturing, biopharma medical devices, forensic and clinical } \\
\text { diagnostics, biohealth services (nonpractitioner), workforce development }\end{array}$ & 214 & 40 & 18.7 \\
\hline Academia & $\begin{array}{l}\text { Department chairs and program directors of life science programs at 2-year and } \\
\text { 4-year undergraduate colleges and universities }\end{array}$ & 145 & 43 & 29.7 \\
\hline Career counselors & $\begin{array}{l}\text { Counseling center directors and staff at 2-year and 4-year colleges and } \\
\text { universities }\end{array}$ & 136 & 25 & 18.4 \\
\hline
\end{tabular}

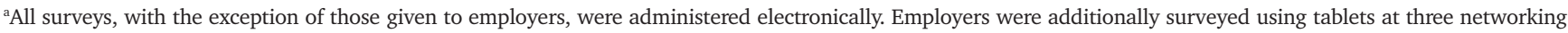
events in the BHCR.

bStudent surveys were distributed to 65 colleges and universities, but only nine confirmed passing the surveys on to their students. 


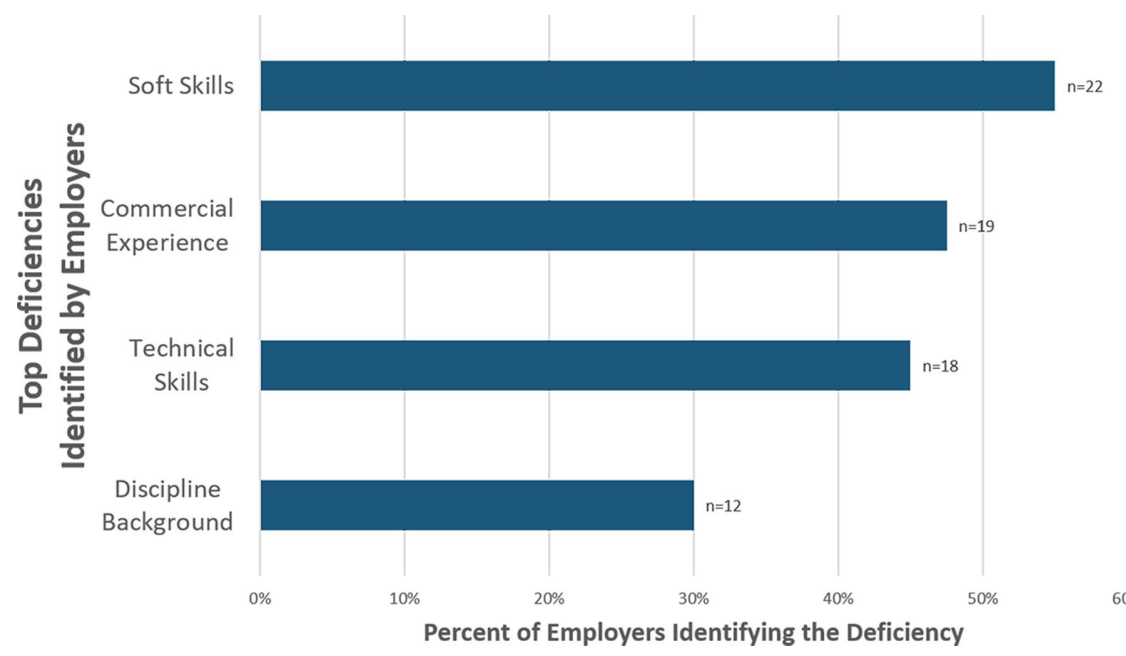

FIGURE 1. Skill deficiencies identified by employers in applicants for entry-level positions. Responses are from $\mathbf{4 0}$ industry representatives in the BHCR who were asked to identify the biggest skills gaps in applicants for bioscience positions. Respondents were allowed to select more than one type of deficiency if applicable to their company's experiences in hiring.

applicants for entry-level positions, as well as industry perceptions of the job readiness of graduates from life science programs. Industry responses are contrasted by the views of department chairs/program directors of life science programs, university career counselors, and students from the same region. We also make recommendations to facilitate improvement in the preparation of graduates for today's bioscience industries. The workforce issues identified in the BHCR appear to be common to other biohealth clusters in the United States (Dahms, 2003; Porter, 2008), and thus the recommendations presented herein have applicability to the national workforce shortage in the biosciences.

\section{UNDERSTANDING WORKFORCE NEEDS OF BIOSCIENCE INDUSTRIES}

The BHCR is composed of an array of life science industries that can be broadly classified as biomanufacturing, biologics, medical devices, clinical and forensic diagnostics, and agricultural technologies. Though distinct in their focus, each company surveyed in the BHCR provided remarkably similar responses in identifying workforce needs and perceptions of student preparation from undergraduate life science programs. For example, of the 40 employers who responded to the MABRC network survey, $94 \%$ indicated that they planned to hire entry-level positions within the year, and of those hires, $87.5 \%$ indicated that the desired educational background was a bachelor's degree (BA or BS). Industry representatives repeatedly shared that far fewer opportunities exist in the BHCR and within specific industries for applicants holding an $\mathrm{MS}$ or $\mathrm{PhD}$ than those with a bachelor's degree. While this seemingly bodes well for graduates seeking employment in industry and the private sector, employers expressed frustration over a lack of job readiness in the vast majority of applicants for entry-level positions. This is a theme echoed by employers across the American economy (Task Force on Apprenticeship Expansion, 2018). When asked to identify the biggest deficiencies in these applicants, $55 \%$ of industry representatives indicated that applicants' professional or soft skills were insufficient (Figure 1). Oral and written communication skills were identified as essential skills for all entry-level positions and represented the weakest skill sets in the majority of job candidates. This is a universal issue to all areas of the workforce (Strauss, 2017), and not restricted to life science industries.

Undergraduate preparation in industry-specific technical skills and business acumen were also recognized as weaknesses in the majority of applicants (Figure 1). However, employers expressed only modest concern with the gaps in technical skill proficiencies if candidates were strong in other areas, especially if applicants displayed a high level of motivation and trainability. The latter attitudes corresponded to companies that provided job-specific technical training for new hires. As one individual stated, though an applicant may have skills with protein purification or gel electrophoresis, for example, once hired, the new employee needs to be trained using protocols, controls, and quality-assurance/ quality-control measures validated by that particular company as opposed to approaches used for academic research. The latter message was stressed by several employers during informal conversations at career fairs and networking events throughout the BHCR. Consistent with this view was the response that employers were not overly concerned about the discipline background of entry-level hires, although all preferred applicants with some type of life science degree (Table 2). Again, the idea of trainability and motivation were more important in job candidates than other attributes.

Individuals associated with talent acquisition have observed that most recent graduates from undergraduate programs have incorrect perceptions of what the life science business environment is like. Broadly, STEM majors as a whole do not have training or experience with for-profit business concepts or a true understanding of quality control and replicability. Applicants for entry-level positions in biosciences appear to do little

TABLE 2. Disciplinary background desired by employers for entry-level positions ${ }^{\mathrm{a}}$

\begin{tabular}{lll}
\hline Agriculture & Cellular and molecular biology & Genetics \\
Biochemistry & Chemistry & GMP quality \\
Bioengineering & Chemical engineering & Microbiology \\
Bioinformatics & Clinical chemistry & Statistics \\
Biology & Engineering & Virology \\
Bioprocessing & Environmental genetics & \\
\hline
\end{tabular}

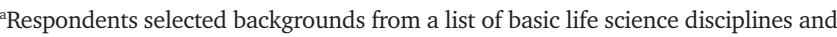
also had the option of providing "other" desired backgrounds. Several employers desired backgrounds in multiple areas for new hires, while other companies intended to hire for multiple positions requiring candidates with diverse life science backgrounds. 
preparation aside from developing a résumé or curriculum vitae before applying for open positions or even before face-toface interviews. This trend appears to be common with many recent college graduates, regardless of disciplinary background (Cappelli, 2012; Dishman, 2016). The end result, according to industry representatives surveyed, is that graduates apply for positions with no understanding of the company's focus. Within the BHCR, the overriding misconception on the part of applicants is that most jobs in biosciences entail biological research. And that the research is consistent with what they experienced as undergraduates during a class or through an independent research experience. In reality, while many companies engage in some type of research, few incorporate entry-level employees into these efforts, and instead are focused on biomanufacturing, product processing, quality control, and other skill sets not commonly associated with undergraduate education (Porter, 2008). Undergraduate student misconceptions are not surprising based on their perceptions; $52.9 \%(n=68)$ believe that they are knowledgeable or very informed about opportunities in nontraditional career tracks, and only $8.8 \%$ believe that they were not exposed to commercially relevant skills during their undergraduate education. Ironically, based on student feedback, the students were apparently more informed than career counselors and academic departments.

Undoubtedly some of the blame for undergraduate misconceptions can be shared with the colleges and universities that are charged with the responsibility of education and career preparedness for students in the BHCR. In fact, this will be evident in the next section, as we examine responses from department chairs, program heads, and career counselors on their understanding of how to prepare students for bioscience careers. However, the life science industry needs to accept some of the criticism as well. Companies in the BHCR have done a poor job of communicating with the academe. This statement actually needs to be parceled out into three audiences: large research institutions that emphasize biomedical research and graduate training, community colleges offering applied associate degrees and certificate programs, and 4-year colleges and universities with a primary focus on undergraduate education. The former two audiences have targeted initiatives either directly with life science business partners or through workforce development programs at the state and local levels. Interestingly, the strength of each type of program is a focus on technical skill development for target audiences that were not identified by the employers as their primary hiring need (i.e., entry-level positions with a bachelor's degree). The weakest relationships identified during the MABRC initiative are between industry and 4-year undergraduate programs. Industry representatives indicated that they want to find ways to more effectively recruit graduates from undergraduate programs in the region. However, their recruitment and promotion strategies have not moved the needle. It could be that the recruiting tactics simply did not resonate with the target audience. Or, when the approaches have drawn student interests, graduates discover that they are lacking in key skills and thus are not job ready for industry. Several employers and talent acquisition officers shared that marketing strategies have relied on pitching industry careers as alternatives to students who did not gain acceptance to medical or graduate schools. While this strategy recognizes that there are many talented students matriculating from colleges and universities in the BHCR, it is not satisfactory in several ways. For one, students considering STEM careers, especially those related to medicine, often decide on this pathway before entering college or shortly thereafter. Rarely do such students switch from one STEM path to another in STEM as undergraduates, unless their academic performance becomes limiting or they participate in an experience (e.g., internship, research, volunteer work) that has a profound impact on career decision making (Thiry et al., 2011; Fry, 2014). Second, students pursuing a curricular program leading to medicine or allied health will generally lack several of the essential skills that employers identified as deficient in most graduates. Thus, these students need to take additional course work or complete industry-specific certificate programs to become job ready. This approach is generally not appealing to either the graduates or parents, who likely have already taken on a significant financial burden for undergraduate education and who also do not see industry being as lucrative and/or prestigious as medicine. Finally, selling a career as a backup plan for when your "dreams do not work out" is akin to marketing a losing sports team to a fan base based on easy parking and convenient seating. The approach fails to identify the mind-set and motivation of such talented students. "Settling" is never an effective marketing strategy.

\section{ARE UNDERGRADUATE LIFE SCIENCE CURRICULA AND CAREER COUNSELING KEEPING PACE WITH INDUSTRY NEEDS?}

The key question underlying the development of a workforce pipeline for biohealth clusters in the United States is whether undergraduates are prepared for careers in the biosciences (Dahms, 2003; Porter, 2008). A closely held belief in academia is that traditional undergraduate curricula adequately prepare graduates for the biosciences workforce. However, employers in the BHCR do not think graduates are job ready. By contrast, $91.7 \%$ of department chairs and program directors surveyed in the BHCR stated that their graduates are not only trained well but are highly prepared for the biosciences workforce. But what is this assessment based upon? When chairs and program directors were asked to assess the technical skills desired by industry that they developed in all graduates, more than $75 \%$ identified skills associated with general chemistry, computer literacy, error handling, statistical analysis, gel electrophoresis, lab notebook maintenance, and general laboratory procedures (Figure 2). What is not known is the level of proficiency achieved by each student for each skill or whether specific skills were merely discussed or were evaluated through hands-on performance. Without knowing the desired competency level of specific skills sets sought by industry, both the employers and department chairs/program heads surveyed are conceivably correct in their perceptions. Similarly, life science chairs and program heads acknowledged that their curricula did not provide training in business acumen but did not believe that their graduates were lacking in soft skills (Figure 3). Of course, the latter is not in agreement with career counselors at these same academic institutions, nor with national trends of graduates from almost any academic discipline (Tate, 2017).

Students, especially those interested in beginning a career rather than more education upon graduation, use the services of their career centers to prepare for the workforce. This was 


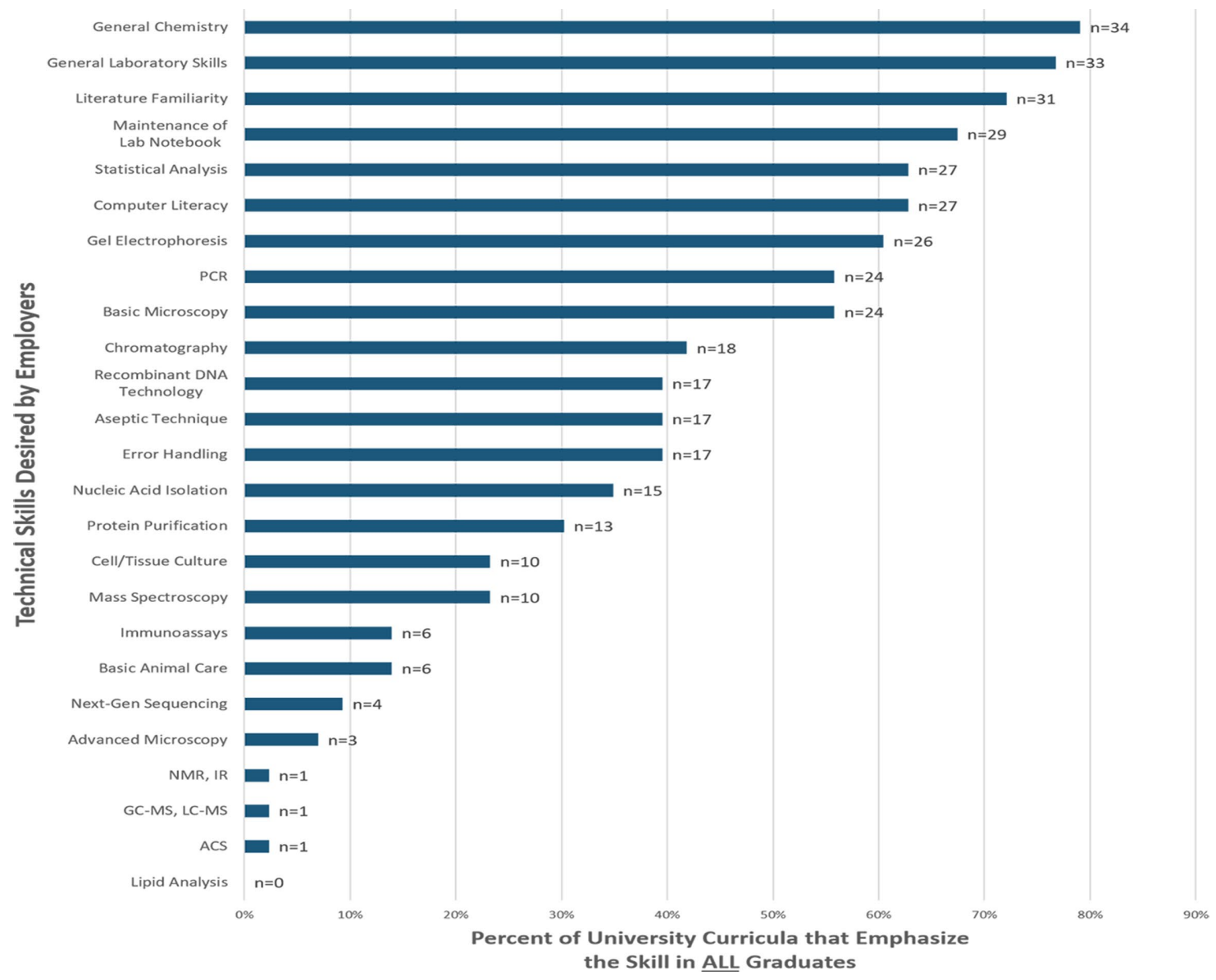

FIGURE 2. Technical skills developed in undergraduate life science programs in the BHCR. Responses are from 43 department chairs and program directors who identified the technical skills desired by bioscience industries that are developed in all graduates from their undergraduate programs. A broad set of technical skills were identified by industry representatives in the BHCR, and thus department chairs and program heads were asked to identify all technical skills developed in all graduates.

evident in our surveys, in that more than $50 \%$ of students reported that they go to their center at least once per year (even though only $16 \%$ of center employees reported that the majority of biology/chemistry majors make at least an annual visit). Feedback from career center counselors and staff indicated that the vast majority $(83.3 \%, n=25)$ mentored undergraduates to pursue an advanced degree (MS or $\mathrm{PhD}$ ) to become qualified for careers in bioscience industries located in the BHCR or elsewhere. Several indicated that this information had been supplied to them by faculty at their home institutions. The counselors' advice is contradictory in that they responded that $68 \%$ of graduates (BS) were job ready for bioscience careers at the time of graduation, yet also admitted that more than $60 \%$ of these matriculating students lack the soft skills highly desired by employers. The survey responses of the career counselors seem to reflect a deficiency in understanding of nontraditional bioscience careers as a whole. This contention is supported by the observation that $96 \%$ of the career counselors grossly underestimated the number of bioscience-related companies and job opportunities in the BHCR and that $72.6 \%$ felt that they were either underinformed or unsure whether they have sufficient knowledge about careers in the biological sciences
(Figure 4). The latter was evident from gauging student interests in pursuing careers in the biosciences: $<15 \%$ of graduates from undergraduate programs sought positions in bioscience industries, and of these students, only $5 \%$ obtained a job in the BHCR. Low student interest in industry jobs is not surprising based on feedback from career counselors and academic departments regarding knowledge and training relevant to bioscience industries.

The responses from various entities at the same colleges and universities indicate disconnection is pervasive within and between stakeholders relevant to undergraduate education, training, and hiring in the BHCR. Perhaps the most significant factor accounting for the disconnect is a lack of communication between stakeholders. Among the institutions surveyed, few partnerships have formed between industry and universities in the region to address long-term workforce needs. Several program heads expressed little to no interest in pursuing such partnerships. All of these programs were at 4-year institutions, supporting the contention that many undergraduate colleges and universities reject job training as part of their purview (Porter, 2008). Even when industry-academic collaborations have formed, most are 
Understanding of Business Environment

Desire to Learn

Motivation

Work Ethic

Effective

Communication

Maturity

Dependability

Independent

Work

Team Skills

Integrity

$0 \%$

$20 \%$

$40 \%$

$60 \%$

$80 \%$

$100 \%$

- $\%$ Chairs/Directors perceiving their graduates lack the skill

a $\%$ Employers identifying the skill as a top priority (top 3)

FIGURE 3. Perceptions of professional skills desired by employers considered to be lacking by department chairs and program directors in their graduates. Industry representatives were asked to identify the top three skills desired in applicants and new hires for entry-level positions. In turn, department chairs and program directors were asked to identify which of these soft skills were deficient in all graduates from their undergraduate programs. focused almost exclusively on technical training with little foundational development into the science and business concepts driving the applications. Business partnerships have been much more common with $\mathrm{PhD}$-granting institutions or, more recently, associated with the development of professional master's programs throughout the region. These relationships have the potential to facilitate industry research and development initiatives, but seemingly will have far less of an impact on promoting workforce development within key demographics. Supporting this view is the frustration expressed by several government and business leaders from the region, who noted that existing industry partnerships have been leveraged more as means for universities to improve resources for faculty research than to provide needed training for the workforce.

\section{WHAT CAN BE DONE TO CURB THE CURRENT TRENDS IN PREPARATION OF UNDERGRADUATES FOR BIOSCIENCES CAREERS?}

Several impediments were identified by the MABRC network that hinder undergraduates from pursuing careers in bioscience industries. These included that 1) students are underinformed or unaware of bioscience opportunities before entering college and remain so at graduation; 2) students are not job ready at the time of graduation; 3) students are mentored to pursue education beyond what is needed and thus are overqualified (by degree) for most of the available jobs in the region; 4) undergraduate programs generally lack any focus on workforce development; and 5) few industryacademic partnerships exist in the region with undergraduate institutions. The reality is that these issues are neither surprising nor restricted to the BHCR. Undergraduate programs in the United States prepare students almost exclusively for traditional career paths, essentially ignoring skill development for alternative careers or the changing workforce environment (Fuhrmann et al., 2011; Strauss, 2017). Lost on most educators is the growing trend for so-called alternative or nontraditional careers becoming the careers of choice in many STEM disciplines (Stephan, 2012; Blank et al., 2017). A clear disconnect exists between academic institutions and the modern workplace (York et al., 2009; Task Force on Apprenticeship Expansion, 2018), jeopardizing the nation's ability to prepare future generations of scientists and engineers equipped with the necessary skills to meet workforce demands. Among the most significant changes identified to address these issues are resources for connecting and improving communication among all stakeholders. This is especially needed for developing dialogue between industry leaders and academic institutions preparing undergraduate students. The reality is that graduates will not pursue alternative careers if they are not 
aware that the opportunities exist, and matriculating students will not be competitive for job openings in nontraditional careers if training and mentoring are not provided as part of their undergraduate education. Dysfunctional attitudes regarding "who" is responsible for job training must be dropped. Instead, colleges and universities need to embrace a larger vision of career preparation for students, and bioscience companies need to remodel their recruitment techniques.

Innovative and integrative approaches are needed in modern undergraduate life science curricula (Becker and Park, 2011) that involve all vested stakeholders in remolding STEM educational and training paradigms (Fry, 2014). This means direct integration of workforce technical and professional skills into undergraduate science curricula (Bybee, 2010; Morella, 2013), with the inclusion of more diverse populations of students (U.S. Department of Education, 2015). Changes should be made within the context of providing real-world experiences beyond the classroom and introduced earlier in students' careers (Campbell et al., 2014), ideally through authentic opportunities (Lopatto, 2007; Thiry et al., 2011) that last longer than a typical 10-week summer program (Russell et al., 2008). The latter is an adaptation of the co-op model used in many engineering programs, in which life science students who are trained in research or internship experiences have the opportunity to return to the same institution or company the next semester or summer. This approach is much more informative to students in their career decisions and provides more benefit to industry partners who have invested in training interns.

Such ambitious goals require partnerships in the educational enterprise, rather than relying solely on institutional silos. Partnerships need to be forged among academia, industry, government agencies, and undergraduate institutions as a means to effectively recruit student cohorts and maximize resources for education and training. While these ideas represent innovative approaches to undergraduate life science education, there is already movement among some colleges and universities to move toward more focus on career preparation. For example, some institutions have integrated professional and/or business skills into individual courses or throughout the curriculum. The latter has occurred at the departmental and university levels (Tate, 2017). Others have taken a further step, recruiting industry scientists or professionals to teach career-specific techniques or courses or to provide career mentoring for undergraduates through workshops, information fairs, or shadowing experiences in industry settings. To an extent, these approaches have been quite common at community colleges for a decade or more (Dishman, 2016). The verdict is still out as to whether any of the educational changes have had an impact on student preparation for the biosciences workforce. However, it is difficult to imagine that the needle has not been moved at least slightly in the right direction. The important lesson is that educational reform is needed to better prepare undergraduate students for emerging careers in the biosciences. A limited number of colleges and universities have responded (or are responding) to the evolving job market by adapting the way they educate their students. There is reason to be optimistic that other 4-year institutions can and will follow suit.

\section{ACKNOWLEDGMENTS}

We thank Christopher Frew and his staff with BioBuzz (www .biobuzz.net) for advice on conducting the employer surveys. This research was supported in part by a National Science Foundation RCN-UBE Incubator grant (1624143) awarded to D.R. and M.T.

\section{REFERENCES}

Araneo, K., Schwebach, J. R., \& Csikari, M. (2017). Advising biology majors about career choices: Resources and information for biology instructors American Biology Teacher, 79(1), 14-21.

Becker, K., \& Park, K. (2011). Effects of integrative approaches among science, technology, engineering, and mathematics (STEM) subjects on students' learning: A preliminary meta-analysis. Journal of STEM Education, 12, 23-37.

BioHealth Capital Region. (2018). Our goal: To become a top 3 biohealth hub by 2023 . Retrieved March 26, 2018, from www.biohealthcapital com

Blank, R., Daniels, R. J., Gilliland, G., Hawgood, S., Hrabowski, F. A., Pollack, M. E., Schlissel, M. S. (2017). A new data effort to inform career choices in biomedicine. Science, 358(1), 1388-1389

Bybee, R. W. (2010). What is STEM education? Science, 329(5995), 996.

Campbell, A. G., Skvirsky, R., Wortis, H., Thomas, S., Kawachi, I., \& Hohmann, C. (2014). NEST 2014: Views from trainees - talking about what matters in efforts to diversify the STEM workforce. CBE-Life Sciences Education, $13,587-592$

Cappelli, P. (2012, June 4). The skills gap myth: Why companies can't find good people. Time Magazine.

Dahms, A. S. (2003). Possible road maps for workforce development in biocommerce clusters, including institutions of higher education. Biochemistry and Molecular Biology Education, 31(3), 197-202.

Dishman, L. (2016, May 17). These are the biggest skills that new graduates lack. Fast Company. Retrieved February 24, 2018, from www.fastcompany .com/3059940/these-are-the-biggest-skills-that-new-graduates-lack

Economic Alliance of Greater Baltimore. (2013). BioHealth in Greater Baltimore: A state of market report. Retrieved June 8, 2017, from www greaterbaltimore.org/Uploadedpdfs/Bio_Report_2013.pdf

Fry, C. L. (Ed.). (2014). Achieving systematic change: A sourcebook for advancing and funding undergraduate STEM education. Washington, DC: Association of American Colleges and Universities.

Fuhrmann, C. N., Halme, D. G., O'Sullivan, P. S., \& Lindstaedt, B. (2011) Improving graduate education to support a branching career pipeline: Recommendations based on a survey of doctoral students in the basic biomedical sciences. CBE-Life Sciences Education, 10(3), 239-249.

Lopatto, D. (2007). Undergraduate research experiences support science career decisions and active learning. CBE-Life Sciences Education, 6, 297-306.

Maryland BioTechnology Center. (2010). Retrieved June 15, 2017, from https://marylandbiocenterorg/Bioscience\%20 of\%20Maryland/Pages/ factsandfigures.aspx

Maryland Department of Commerce. (2018). BioHealth and Life Sciences Retrieved June 23, 2017, from https://open.commerce.maryland.gov/ biohealth-technology/

Morella, M. (2013, January 31). Many high schoolers giving up on STEM. U.S News and World Report. Retrieved December 1, 2015, from www.usnews .com/news/blogs/stem-education/2013/01/31/report-many-high -schoolers-giving-up-on-stem

National Institutes of Health. (2012). Biomedical Research Workforce Working Group report. Bethesda, MD.

Porter, S. (2008, May 9) Workforce shortages in biotechnology, part I. Why is this a problem? Retrieved March 4, 2018, from https://digitalworldbiology .com/archive/workforce-shortages-biotechnology-part-i-why-problem

Roach, M., \& Sauermann, H. (2017). The declining interest in an academic career. PLOS ONE, 12(9), e0184130

Russell, S. H., Hancock, M. P., \& McCullough, J. (2008). Benefits of undergraduate research experiences. Science, 316, 548-549. 
Stephan, P. (2012). How economics shapes science. Cambridge, MA: Harvard University Press.

Strauss, V. (2017, December 20). The surprising thing Google learned about its employees - and what it means for today's students. Washington Post. Retrieved December 21, 2017, from www.washingtonpost.com/news/ answer-sheet/wp/2017/12/20/the-surprising-thing-google-learned -about-its-employees-and-what-it-means-for-todays-students/?utm _term $=.56 \mathrm{e} 8669686 \mathrm{c} 8$

Task Force on Apprenticeship Expansion. (2018). Final report to the President of the United States. Retrieved May 16, 2018, from www.dol.gov/ apprenticeship/docs/task-force-apprenticeship-expanision-report.pdf

Tate, E. (2017, January 30). Liberal arts college tries new approach to teaching soft skills. Inside Higher Ed. Retrieved January 30, 2017, from www .insidehighered.com/news/2017/01/30/liberal-arts-college-tries-new -approach-teaching-soft-skills
TEConomy and Biotechnology Innovation Organization. (2016). The value of bioscience innovation in growing jobs and improving quality of life. Retrieved February 26, 2018, from www.bio.org/sites/default/files/ BIO\%202016_Report_FINAL_DIGITAL.pdf

Thiry, H., Laursen, S. L., \& Hunter, A.-B. (2011). What experiences help students becomes scientists? A comparative study of research and other sources of persona and professional gains for STEM undergraduates. Journal of Higher Education, 82(4), 357-388.

U.S. Department of Education. (2015). Science, Technology, Engineering, and Math: Education for Global Leadership. Retrieved December 3, 2015, from www.ed.gov/stem

York, A. S., McCarthy, K. A., \& Darnold, T. C. (2009). Teaming in biotechnology commercialization: The diversity-performance connection and how university programmes can make a difference. Journal of Commercial Biotechnology, 15(1), 3-11. 